\title{
Non-linear Preferences on Bioethanol in South Korea ${ }^{\dagger}$
}

\author{
Jeong Hwan Bae*
}

ABSTRACT: Recently, there has been a debate as to whether bioethanol should replace some portion of gasoline for fuels in South Korea, as energy security as well as climate change issues are rising as a significant national agenda. However, a considerable amount of subsidy will be required to compensate for the higher price of bioethanol-blended gasoline. In this context, government subsidy will obtain justification only when the positive social gains from consuming bioethanol for fuels can exceed the negative social costs. Through a nation-wide choice experimental survey, we examine if South Koreans have a positive value as well as non-linear preferences on substituting bioethanol for gasoline. The results reveal that the willingness to pay for purely domestic bioethanol-blended gasoline within $10 \%$ is about 52 KRW; Koreans have concave preferences on the blending ratio of bioethanol to gasoline. The turning point of the blending ratio of bioethanol was $6.5 \%$. Also, we found inverse U-shaped curve between income and bioethanol choice probability and the turning point of the income was calculated as 250 299million KRW. Politically conservative propensity advocates uses of bioethanol blended gasoline, but awareness on bioethanol or more weights on environmental conservation have significantly negative effects on the choice of bioethanol. However, the design of the survey questionnaire is incompatible with the RFS of Korea and assumes orthogonality among the following four interrelated attributes: (i) domestic or offshore procurement of feedstocks in the case of domestic production, (ii) domestic production or import of bioethanol, (iii) the blending ratios, and (iv) the retail price increases. In addition, the results of model estimation and of model selection test are not definite. Hence, the results in this study should not be directly applied to the design of the specifics of the Korean RFS. Hence, the results in this study require cautions in applying to the design of the Korean RFS policy.

Keywords : Renewable Fuel Standard, Bioethanol, Non-linear preferences, Turning point, Choice Experiment

JEL 분류 : Q42; Q51

Received: July 18, 2014. Revised: September 17, 2014. Accepted: September 19, 2014.

${ }^{\dagger}$ I really appreciate three anonymous referees for the precious comments. All potential problems in this paper totally belong to the author's responsibility.

* Department of Economics, Chonnam National University, Yongbongro 77 Bukgu, Gwangju, Republic of Korea(e-mail: jhbae@jnu.ac.kr) 


\title{
국내 바이오에탄올에 대한 비선형적 선호에 관한 연구
}

\author{
배 정 환*
}

요 약 : 최근 우리나라에서도 바이오에탄올 혼합을 의무화하는 제도 도입을 준비하고 있다. 바 이오에탄올은 기후변화에 대응하기위한 수단일 뿐만 아니라 에너지 안보 측면에서 휘발유에 대한 유력한 대체연료이다. 그러나 일반 휘발유보다 판매가격이 더 높은 바이오에탄올 혼합 휘 발유를 유통시키기 위해서는 정부 지원이 선행되어야 한다. 따라서 바이오에탄올 소비로 인한 편익이 비용보다 높다면 정부 지원의 정당성이 확보될 수 있을 것이다. 본 연구는 전국의 휘발 유 자동차 운전자를 대상으로 바이오에탄올 선호도를 조사하였다. 패널로짓모형을 이용하여 $3 \sim 10 \%$ 바이오에탄올 혼합 휘발유에 대한 속성을 분석한 결과 국산원료를 이용한 에탄올 지불 용의액이 리터당 52 원으로 나타났다. 한편 바이오에탄올 혼합률이 증가할수록 역 U자형의 비 선형 선호도를 갖는 것으로 추정되었고, 전환점에서 바이오에탄올 혼합률은 $6.5 \%$ 로 나타났다. 또한 소득수준과 바이오에탄올 선호간에도 역 U자형의 관계가 나타났고, 전환점 소득 구간이 250 299만 원인 것으로 나타났다. 한편 정치적으로 보수 성향일수록 바이오에탄올혼합유를 선 호하고, 바이오에탄올에 대한 사전 지식이 있거나 환경보전에 대한 중요성이 높을수록 바이오 에탄올혼합유 이용에 비판적인 것으로 나타났다. 다만 본 연구는 휘발유에 바이오에탄올의 혼 유를 의무화하는 정책에 대한 소비자의 지불용의액을 실증분석하고자 하였지만, 우리나라에서 법제화된 RFS 제도에 직접적으로 부합하게 설문이 설계되지 않았고, 바이오에탄올의 원료조 달, 제조, 의무혼합비율, 가격인상액 간에 직교관계를 가정했다는 한계가 존재한다. 또한 모형 추정결과가 확정적이지 않다는 점에서, 위 결과를 우리나라에서 법제화된 RFS 제도에 그대로 적용하는 데는 주의를 요한다.

주제어 : 재생연료의무화제도, 바이오에탄올, 비선형선호, 전환점, 선택실험법

접수일(2014년 7월 18일), 수정일(2014년 9월 17일), 게재확정일(2014년 9월 19일)

* 전남대학교 경제학부 부교수(e-mail: jhbae@jnu.ac.kr) 


\section{Introduction}

Renewable Fuel Standard (RFS) was enacted in South Korea in June of 2013 and will be implemented in the beginning of 2015. The United States, Brazil and several European countries have already implemented the RFS in order to substitute fossil fuels with biofuels, such as bioethanol, biodiesel or biogas. Nontheless, concerning the utilization of biofuels, there have been on-going debates on issues such as agflation due to the excessive fuel demand on feedstock (World Bank, 2008), destruction of tropical forests and inefficiency of government subsidy on agriculture for biofuel feedstock (Hill et al., 2006). In numerous countries that have implemented the RFS, such as the USA and EU countries, biofuels have been produced and blended with petroleum even if the prices of biofuels were not competitive relative to petroleum prices. A substantial amount of subsidy as well as oil tax exemption has been paid to the suppliers of feedstock for biofuels, biofuel producers and consumers of biofuels (Ferris and Joshi, 2004; de Gorter and Just, 2007; Vedenov and Wetzstein, 2008).

Before the government intervenes in the bioethanol market, it is important to investigate preference structure of potential consumers on the bioethanol as well as a willingness to pay (WTP) for a higher bioethanol-blended gasoline price relative to the conventional gasoline price. Positive WTP for bioethanol might justify the introduction of bioethanol through a government subsidy. Furthermore, if there exists a non-linear preference on bioethanol, it will be optimal to provide bioethanol at the turning point, where the marginal utility from consuming bioethanol is equal to zero. Moreover, the appropriate amount of government subsidy should be based on the consumer's WTP for bioethanol as well as the expected social costs.

There are several studies that have estimated consumer preferences and WTP for bioethanol in the United States. Vedenov and Wetzstein (2008) derived an optimal 
U.S. ethanol subsidy as $\$ 0.22 /$ gallon (54 KRW/liter $\left.{ }^{1}\right)$ ) by estimating a theoretical model on the social benefits of bioethanol, such as enhanced environmental quality, fuel security and economic development. According to Solomon and Johnson (2009), the WTP for biomass bioethanol was estimated as 40 cents per gallon (98.2 KRW/ liter). They used a fair share survey and a multi-part, split sample contingent valuation method for valuing biomass bioethanol. Petrolia et al. (2010) estimated values of E10 and E85 by applying the contingent valuation method with satisfaction questions; they discovered that the WTP for E10 was between 6 12 cents/gallon (15 30 KRW/liter) while the WTP for E85 was between 12 15 cents/gallon (30 37 KRW/liter). Further, they also found that politically liberal groups had higher WTP for E10 as well as E85.

Although previous studies have shown positive benefits from substituting bioethanol for gasoline, it is not known as to whether South Koreans have a positive value on the production of bioethanol and if they have linear or non-linear preferences on bioethanol supply depending on different bioethanol production pathways.

Once the appropriate amount of subsidy is determined on per liter of bioethaol production, the next step is how much of the bioethanol can be blended with gasoline. The maximum plausible blending ratio is considered as $10 \%$ (E10) because the modification of engine or flex-fuel vehicles are not available at the present stage of RFS in Korea (Lim, 2012). For the given E10, petroleum companies have a desire to protect the market share of petroleum as large as possible, whereas bioethanol manufacturers expect to increase the bioethanol blending ratios as high as possible. Up till now, there has been no study on the amount of bioethanol Korean consumers want to demand and which specific group prefers to consume bioethanol over gasoline. Therefore, this study contributes to a desirable and stable landing of the RFS policy in Korea by examining the relationship between consumer preferences

1) Annual average a dollar value in Korean won was 1,126 in 2012. 
and bioethanol blending ratios.

The primary objective of this study is to measure WTP for higher prices of bioethanol-blended gasoline relative to conventional gasoline prices. WTP for domestic bioethanol can be interpreted as the marginal gains from industrial and agricultural development, energy security and environmental effects. The second purpose is to examine if consumer preferences are proportional or non-linear to the increase of the bioethanol blending ratio. In Petrolia et al.(2010), the study presented that E85 is preferred over E10 in the United States. However, they also found that other options, such as the use of a more efficient hybrid car or public transit, are more preferred over bioethanol. This implies that consumer preferences might be non-linear for higher bioethanol blending ratios if other options are considered. Third, we investigate if different income, political propensity, awareness on bioethanol or environmental conservation, and other personal characteristics affect choice of bioethanol blended gasoline. According to Solomon and Johnson (2009) and Petrolia et al. (2010), liberal and higher income people have higher WTP for bioethanol (E10). However, Korean consumers might have a different preference structure compared to other countries.

For the purpose of investigating those three objectives, a choice experiment approach was employed in order to derive Korean petroleum consumers' WTP on social gains from bioethanol production. E3, E5 and E10 with three different production pathways which are domestic bioethanol with domestic feedstock, domestic bioethanol with imported feedstock, and imported bioethanol were considered as attributes of alternative bioethanol. Respondents were provided with the potential benefits as well as costs before they chose the most preferred option among the given choice alternatives.

In the next section, both theoretical and estimation models for the choice experiment are described. Section III summarizes the survey design for the choice experiment and descriptive statistics. In section IV, estimates for attributes are 
described and the results of basic as well as extended panel econometric moels are explained. Section V discusses the findings and policy suggestions.

\section{Models for Choice Experiment}

One of the most widely used methods for examining the stated preferences in fields such as communication, transportation, environment and medicine, amongst others, is the choice experiment (Batt \& Katz, 1997; Hensher, 1994; Hanley et al., 1998; Slothuus et al., 2002). In the choice experiment, potential consumers are asked to choose the most preferred alternative among various choice sets. The alternatives in each set are composed of various attributes with different levels. The choice experiment is theoretically based on the random utility model, which assumes that a consumer's utility is split into representative utility $\left(V_{n i}{ }^{\prime} \theta\right)$ and random component $\left(\varepsilon_{n i}\right)$ reflecting unobserved individual idiosyncrasies of tastes (Louviere et al., 2010). The random component follows a Type I extreme-value or the Gumbel distribution:

$$
U_{n i}=V_{n i}{ }^{\prime} \theta+\varepsilon_{n i}, F\left(\varepsilon_{n i}\right)=\exp \left(-\exp \left(-\varepsilon_{n i}\right)\right)
$$

A potential consumer $\mathrm{n}$ chooses an alternative $\mathrm{i}$ if his utility $U_{n i}$ from choosing alternative $\mathrm{i}$ exceeds $U_{n j}$ from an alternative $\mathrm{j}$. The choice probability can be transformed into a conditional logit model:

$$
\begin{aligned}
& \operatorname{Prob}\left(Y_{n}=i\right)= \frac{\exp \left(V^{\prime}{ }_{n i} \theta\right)}{\sum_{j=1}^{J} \exp \left(V^{\prime}{ }_{n j} \theta\right)}, \\
& V_{n i}=\left[X_{n i}, Y_{i}\right], \theta=\left[\alpha^{\prime}, \beta^{\prime}\right]
\end{aligned}
$$


The observable utility $V_{n i}$ is affected by individual specific variables $\left(X_{n i}\right)$ as well as alternative specific attributes $\left(Y_{i}\right)$. If there is no individual specific effect, the conditional logit model becomes the multinomial logit model (Greene, 2008).

The conditional logit model can be transformed into a panel logit model when the data has a panel structure. In this choice experiment, each respondent is required to answer a series of choice sets with different attribute levels and different scenarios. This panel logit model assumes that the random component can affect the repeated choices by each respondent, which implies that the respondent's present choices are dependent on past choices (Train, 2009). In the panel logit model, an individual's utility from alternative $\mathrm{j}$ in choice situation $\mathrm{s}$ consists of both representative utility and random component.

$$
\begin{aligned}
& U_{n j s}=V_{n j s}^{\prime}+\varepsilon_{n j s} \\
& \operatorname{Prob}\left(Y_{n s}=j\right)=\frac{\exp \left(V^{\prime}{ }_{n j s} \theta\right)}{\sum_{j=1}^{J} \exp \left(V^{\prime}{ }_{n i s} \theta\right)}
\end{aligned}
$$

Individual or situation specific effects can be considered as a fixed or a random effect panel model (Greene, 2008). The fixed effect panel logit model is typically the same with the conditional logit model because the conditional probability approach is applied to fit the fixed effect panel logit model (STATA, 2009).

When the unobserved factors of the panel data are correlated over different choice situations, the panel probit model can be alternatively applied for the choice experiment. Error terms of the panel probit model are normally distributed with a mean vector of zero and covariance matrix $\Omega$; the probability density function of the error terms is $\Theta\left(\varepsilon_{n j s}\right)$. 


$$
\begin{aligned}
& P_{n j s}=\operatorname{Prob}\left(V_{n j s}+\varepsilon_{n j s}>V_{n i s}+\varepsilon_{n i s}\right)(j \neq i), \\
& \Theta\left(\varepsilon_{n j s}\right)=\frac{\exp \left(-(1 / 2) \varepsilon^{\prime}{ }_{n j s} \Omega^{-1}{\varepsilon^{\prime}}{ }_{n j s}\right)}{(2 \pi)^{J / 2}|\Omega|^{1 / 2}}
\end{aligned}
$$

The panel logit fixed, random effect models and panel probit model will be applied in order to estimate the parameters of attributes in bioethanol production.

The representative utility for choosing the most preferred one among the various bioethanol blended fuels consists basically of the attributes of bioethanol $\left(A_{n j}\right)$, monetary attribute of bioethanol $\left(C_{n j}\right)$, and personal characteristics such as income $\left(M_{i}\right)$, age, sex, education, political propensity, and environmental awareness $\left(Z_{i}\right)$. Constant term in the panel logit model for choice experiment is frequently called alternative specific constant (ASC) and more details on the ASC will be discussed in the next section. Attributes of bioethanol blended fuels include three types (domestic ethanol with domestic feedstock; domestic ethanol with imported feedstock; imported ethanol) in ethanol production methods and three levels (3\%; $5 \% ; 10 \%)$ in bioethanol blending ratios. Other attributes such as reduction of $\mathrm{CO}_{2}$ emission, environmental improvement, and other indirect benefits are not included as attributes because of correlation problems among the alternatives in the choice sets 2 ). Attributes in alternative $\mathrm{j}$ change across respondent $\mathrm{n}$ as well as choice set $\mathrm{s}$ but income and other personal characteristics do not change across either alternative $\mathrm{j}$ or choice set $\mathrm{s}$.

$$
V_{n i s}{ }^{\prime} \theta=A S C+\beta_{A} A_{n j s}+\beta_{C} C_{n j s}+\beta_{M} M_{n}+\beta_{Z} Z_{n}+\varphi_{n j s}
$$

where $A_{n j s}^{\prime}=\left[F_{n j s}^{D}, F_{n j s}^{I}, E_{n j s}^{I}, M i x_{n j s}\right]$

2) It is straightforward that the degree of $\mathrm{CO}_{2}$ emssion reduction or environmental improvement will be positively correlated with the amount of bioethanol blending ratios. 
$\left(F_{n j s}^{D}\right.$ : Dummy for domestic bioethanol with domestic feedstock, $F_{n j s}^{I}$ : Dummy for domestic bioethanol with imported feedstock, $E_{n j s}^{I}$ : imported bioethanol, $M I X_{n j s}$ : Bioethanol blending ratio)

$$
Z_{n}^{\prime}=\left[\text { age, sex }, \text { edu }, D_{n}^{\text {cons }}, D_{n}^{\text {neutral }}, D_{n}^{\text {liberal }}, e n v_{n}^{1}, e n v_{n}^{2}, e n v_{n}^{3}\right]
$$

(edu: education, $D_{n}^{\text {cons }}$ : dummy for politically conservative group, $D_{n}^{\text {neutral }}$ : dummy for politically neutral group, $D_{n}^{\text {liberal }}$ : dummy for politically liberal group, $e n v_{n}^{1}$ : relative importance of ethanol on reduction of $\mathrm{CO}_{2}$ emission to other benefits such as development of rural economy, relevant industrial development, and substitution for fossil fules, $e n v_{n}^{2}$ : relative importance of environmental conservation compared with economic growth and fairness of income, $e n v_{n}^{3}$ : awareness of bioethanol for transport fuel)

\section{Choice Experiment Design}

A face-to-face choice experimental survey was conducted between November and December of 2012 for 500 car owners in Korea, and a stratified sampling method was applied. Before the final version of the survey was conducted, a pretest and a review of the focus group were implemented.

The final version of the survey ${ }^{3}$ ) consists of three sections: 1) background questions on car ownership, fuel cost, knowledge on bioethanol, benefits of bioethanol production, 2) description of various types of bioethanol with different economic and environmental effects and choice questions, and 3) socio-demographic questions.

In the first section of the survey, the questions were based on the following: ownership of car, gender, age, importance of fuel price, distance to fuel station,

3) Figure a2 in the appendice shows the entire final version of survey questionnaire. 
brand name of fuel station, auxiliary services of fuel station in the choice of fuel station, types of car, average driving distance per day, purpose of driving a car, average fuel economy, monthly fuel cost, recognition of bioethanol as fuel, importance of various effects of bioethanol as fuel, and importance of various bioethanol supportive policies.

Section two includes the comparison of benefits and costs among domestic bioethanol with domestic feedstock, domestic bioethanol with imported feedstock and imported bioethanol as well as the attributes and levels of bioethanol-blended petroleum (Table a1). Next, we explained how the different blending ratios of bioethanol had different environmental effects (mitigation of green house gases) (Table a2). In section three, each respondent was asked to choose the most preferred alternative among three different fuels: two bioethanol-blended gasoline fuels (E3, E5, or E10) and opt-out option which means $100 \%$ gasoline fuel. So if one respondent chose one between two bioethanol options, a dummy for this choice had one, while if he/she chose opt-out option, the dummy had zero. The respondent had to answer nine choice sets with different combinations of attributes for the alternative fuels (Figure a1). Before the respondents could answer the choice questions, the attributes and levels of alternative bioethanol were described (Table a3).

Our sample was selected from car owners over 19-years-old who live in the Republic of Korea. In the sampling process, spatial as well as sex, age, education and income distribution were considered as impartially as possible. The number of samples for each region was determined according to the proportion of the total population in the region. Among the 500 samples, approximately $76 \%$ of respondents were male and $72 \%$ were between their 40 s and 50 s (Table a4). Approximately $95 \%$ of respondents graduated at least high school. About $60 \%$ of respondents earn between 3,000 and 5,000 thousand KRW monthly. The survey results of 497 respondents were used in the analysis because there were three missing answers in the survey questions. 
Each set includes choices among two alternative ethanol and an opt-out gasoline option. Each alternative ethanol varies with different attributes: method of supply, blending ratio and increases in the purchase price of ethanol-blended petroleum per liter. Ethanol supply methods consist of three different pathways: 1) domestic production of ethanol with domestic feedstock, 2) domestic production of ethanol with imported feedstock and 3) purely imported ethanol. The ethanol blending ratio is divided into E3, E5 and E10. Price increases in petroleum blended with ethanol are split into 20,80 and $120 \mathrm{KRW}$ increases per liter relative to pure petroleum. The price levels are chosen according to the prediction on the production costs of bioethanol blended gasoline (Korea Alcohol and Liquor Industry Association, 2012). According to the prediction on the production costs, total production cost of E3 is estimated as around 20 70KRW/liter depending on different production options. There is no prediction on production costs for E5 or E10, but if economy of scale is considered in the calculation of production costs, the price levels in our choice experiment seem to be reasonable4).

Because the attribute on bioethanol pathways is qualitative, an effect coding method was used intead of the dummy coding method for the purpose of avoiding perfect collinearity or the dummy variable trap (Beck and Dorte, 2005). In table 1, the third level, as a reference point, is perfectly correlated with the first and second levels by encoding it as -1 . Hence, the parameter for the third level (imported bioethanol) can be indirectly derived by a minus sum of the estimated parameters for the first level (domestic bioethanol with domestic feedstock) and the second one (domestic bioethanol with imported feedstock). Owing to the effect coding, the alternative specific constant (ASC) term can be interpreted as a quantified utility level for choosing an opt-out option (pure gasoline).

4) We admit that it is plausible that increase in the production of bioethanol would raise feedstock costs which was pointed out by an anonymous referee. Thus, more delicate survey design for price changes depending on different feedstock as well as various blending ratios should have been considered. 
〈Table 1〉 Effect coding for the bioethanol production pathway variable

\begin{tabular}{c|c|c}
\hline Bioethanol production pathway & $E C 1$ & $E C 2$ \\
\hline Domestic bioethanol with domestic feedstock & 1 & 0 \\
\hline Domestic bioethanol with imported feedstock & 0 & 1 \\
\hline Imported bioethanol & -1 & -1 \\
\hline
\end{tabular}

The choice experiment on bioethanol consists of 9 choice sets for each respondent. SPSS (version 19) was used to extract the orthogonal choice sets. Unrealistic choice sets were excluded by comparing the levels of attributes within the choice set (Holmes \& Adamowicz, 2003). For example, choice sets with low petroleum price increases, high bioethanol blending ratio and domestic feedstock were removed. Also, choice sets were selected in order to consider the trade-off relationship between financial and non-financial attributes (Champ et al., 2003). Finally, 8,946 choices were selected for the estimation of parameters ${ }^{5}$.

\section{Results}

\section{Parameter estimates for attributes}

Parameter estimation on the attributes of ethanol was performed by using the panel logit models for the fixed effect and random effect models as well as the panel probit model. There were slight differences among the pseudo $\mathrm{R}^{2}$ for the fixed effect, random effect panel logit and panel probit models. As the Hausman test indicates that the decision on the null hypothesis on the no correlation between explanatory variables and residual term is indeterminant due to the negative test statistics. Therefore, we compare the estimation results from the panel logit fixed effect, random effect and panel probit models based on the Akeike Information

5) Total number of observations (8946) was caculated from multiplying the number of respondents (497) by the number of profiles $(18=9 * 2)$. 
Criterion (AIC) and Baysian Information Criterion (BIC). For both criterion, fixed effect model is better fitted than the other two models. So the fixed effect model is chosen as the estimation method.

The price increase of ethanol-blended gasoline reduced the likelihood of choosing an alternative fuel. The use of domestic feedstock for producing domestic bioethanol increased the likelihood of choosing an alternative fuel. People have a positive preference on bioethanol that is domestically produced by imported feedstock; however, the preference weights were very small relative to domestic bioethanol with domestic feedstock and also, statistically insignificant. The coefficients of imported bioethanol were calculated as the minus sum of the estimated coefficients of domestic ethanol with domestic feedstock and domestic ethanol with imported feedstock. The coefficients show that people have strongly negative preferences on imported ethanol.

As more ethanol was blended into the petroleum, the probability of choosing ethanol increased; however, the square term of the ethanol blending ratio was negative for all models. This means that people's preference on the bioethanol blending ratio shows an inverse $U$ shaped curve. Similarly, there is an inverse $U$ shaped relationship between the choice likelihood of bioethanol blended fuels and income levels. Therefore, at the left hand side of turning points, the more the bioethanol blending ratio as well as the higher people's income levels, the higher probability of choosing the bioethanol blended fuels is expected. Meanwhile, at the right hand side of the turning points, as people have higher income level as well as higher blending ratios, the likelihood of choosing the bioethanol blended fuels falls.

The ASC terms in the panel logit random effect as well as in the panel probit models have negative signs, which implies that people might have a negative utility from choosing pure gasoline instead of ethanol-blended gasoline. 
〈Table 2〉 Parameter estimation on basic bioethanol choice models

\begin{tabular}{c|c|c|c}
\hline Variables & Panel logit FE & Panle logit RE & Panel probit \\
\hline$C_{n j}$ & $-0.030^{* * *}(0.002)$ & $-0.029^{* * *}(0.002)$ & $-0.018^{* * *}(0.001)$ \\
\hline$F_{n j s}^{D}$ & $1.554^{* * *}(0.107)$ & $1.509^{* * *}(0.107)$ & $0.922^{* * *}(0.064)$ \\
\hline$F_{n j s}^{I}$ & $0.034(0.085)$ & $0.028(0.084)$ & $0.018(0.051)$ \\
\hline$E_{n j s}^{I}$ & -1.588 & -1.537 & -0.94 \\
\hline$M L X_{n j s}$ & $0.623^{* * *}(0.152)$ & $0.690^{* * *}(0.152)$ & $0.391 * * *(0.091)$ \\
\hline$\left(M L X_{n j s}\right)^{2}$ & $-0.048^{* * *}(0.011)$ & $-0.053^{* * *}(0.011)$ & $-0.030^{* * *}(0.007)$ \\
\hline$M_{i}$ & $0.261 * * *(0.089)$ & $0.261 * * *(0.089)$ & $0.156^{* * *}(0.053)$ \\
\hline$\left(M_{i}\right)^{2}$ & $-0.026^{* * *}(0.008)$ & $-0.026^{* * *}(0.008)$ & $-0.016^{* * *(0.005)}$ \\
\hline $\mathrm{ASC}$ & & $-1.160^{*}(0.638)$ & $-0.594(0.385)$ \\
\hline $\mathrm{LL}(0)$ & -5961 & -5961 & -5961 \\
\hline $\mathrm{LL}(\mathrm{B})$ & -5422 & -5483 & -5483 \\
\hline Peudo $\mathrm{R}^{2}$ & 0.090 & 0.080 & 0.080 \\
\hline $\mathrm{AIC}$ & 10857 & 10983 & 10984 \\
\hline $\mathrm{BIC}$ & 10907 & 11047 & 11048 \\
\hline
\end{tabular}

Notes: $C_{n j}$ : price changes of bioethanol blended gasoline, $F_{n j s}^{D}$ : Dummy for domestic bioethanol with domestic feedstock, $F_{n j s}^{I}$ : Dummy for domestic bioethanol with imported feedstock, $E_{n j s}^{I}$ : imported bioethanol, $M I X_{n j s}$ : Bioethanol blending ratio, $M_{i}$ : income level, ASC: Alternative specific constant, LL(0): Loglikelihood without regressors, LL(B): Loglikelihood with regressors, Pseudo R2: 1-LL(B)/LL(0)

Standard errors are in parenthesis. $*, * *$, and $* * *$ indicate statistical significance at the $10 \%$, $5 \%$, and $1 \%$ levels, respectively.

\section{Parameter estimates for individual characteristics}

We examined if personal characteristics and their interaction terms with the dummy variable for doestic bioethanol with the domestic feedstock can affect the probability of choosing the alternative bioethanol-blended gasoline. As table 3 shows, there is no statistically significant parameter for those variables. Although they are not significant, female, younger, and higher educated people are inclined to choose bioethanol blended gasoline more frequently. There is no significant 
interaction terms between variables on sex, age, and education and a dummy variable on domestic bioethanol with domestic feedstock.

〈Table 3〉 Extended bioethanol choice models with personal characteristics

\begin{tabular}{|c|c|c|c|}
\hline Variable & $f e 1$ & $f e 2$ & fe3 \\
\hline$C_{n j}$ & $-0.030 * * *(0.002)$ & $-0.030^{* * *}(0.002)$ & $-0.030 * * *(0.002)$ \\
\hline$F_{n j s}^{D}$ & $1.685^{* * *}(0.137)$ & $1.537 * * *(0.254)$ & $1.926 * * *(0.283)$ \\
\hline$F_{n j s}^{I}$ & $0.034(0.085)$ & $0.034(0.085)$ & $0.034(0.085)$ \\
\hline$E_{i j s}^{I}$ & -1.719 & -1.571 & -1.96 \\
\hline$M I X_{n j s}$ & $0.623 * * *(0.152)$ & $0.623 * * *(0.152)$ & $0.623 * * *(0.152)$ \\
\hline$\left(M I X_{n j s}\right)^{2}$ & $-0.048^{* * *}(0.011)$ & $-0.048^{* * *}(0.011)$ & $-0.048^{* * *}(0.011)$ \\
\hline$M_{i}$ & $0.260 * * *(0.089)$ & $0.263^{* * *}(0.089)$ & $0.264 * * *(0.089)$ \\
\hline$\left(M_{i}\right)^{2}$ & $-0.026^{* * *}(0.008)$ & $-0.026^{* * *}(0.008)$ & $-0.027 * * *(0.008)$ \\
\hline Sex & $0.057(0.068)$ & & \\
\hline$F_{n j s}^{D} * \operatorname{Sex}$ & $-0.171(0.112)$ & & \\
\hline Age & & $-0.002(0.003)$ & \\
\hline$F_{n j s}^{D} *$ Age & & $0.000(0.005)$ & \\
\hline Edu & & & $0.075(0.048)$ \\
\hline$F_{n j s}^{D} * \mathrm{Edu}$ & & & $-0.108(0.076)$ \\
\hline $\mathrm{LL}(0)$ & -5961 & -5961 & -5961 \\
\hline LL(B) & -5420.5 & -5421.24 & -5420.25 \\
\hline Peudo $\mathrm{R}^{2}$ & 0.091 & 0.091 & 0.091 \\
\hline
\end{tabular}

Notes: $C_{n j}$ : price changes of bioethanol blended gasoline, $F_{n j s}^{D}$ : Dummy for domestic bioethanol with domestic feedstock, $F_{n j s}^{I}$ : Dummy for domestic bioethanol with imported feedstock, $E_{i j s}^{I}$ : imported bioethanol, $M I X_{n j s}$ : Bioethanol blending ratio, $M_{i}$ : income level, ASC: Alternative specific constant, LL(0): Loglikelihood without regressors, LL(B): Loglikelihood with regressors, Pseudo R2: 1-LL(B)/LL(0)

Standard errors are in parenthesis. $*, * *$, and $* * *$ indicate statistical significance at the $10 \%$, $5 \%$, and $1 \%$ levels, respectively. 


\section{Parameter estimates for different political propensity}

The political propensity was divided into conservative, neutral and progressive groups depending on direct as well as indirect questions. Before people answer direct questions on if they are more likely to belong to conservative, neutral, or progressive groups, they had to answer indirect questions on which factors among income fairness, economc efficiency, and environmental coservation they consider most importantly.

The dummy variable for the conservative group affected the probability of choosing bioethanol blended fuels positively and significantly as shown in the FE4 model of table 4. On the contrary, People who belong to progressive group are less inclined to choose the bioethanol blended gasoline. For the neutral group, the parameter estimate was insignificant and negative on the probability of choosing the bioethanol blended gasoline. All the parameter estimates for interaction terms of political groups with the dummy for domestic bioethanol with domestic feedstock were statistically insignificant.

〈Table 4〉 Extended bioethanol models with different political propensity

\begin{tabular}{c|c|c|c}
\hline Variable & $F e 4$ & $F e 5$ & Fe6 \\
\hline \multirow{2}{*}{$C_{n j}$} & $-0.030^{* * *}$ & $-0.030^{* * *}$ & $-0.030^{* * *}$ \\
& $(0.002)$ & $(0.002)$ & $(0.002)$ \\
\hline \multirow{2}{*}{$F_{n j s}^{D}$} & $1.605^{* * *}$ & $1.528^{* * *}$ & $1.534^{* * *}$ \\
& $(0.113)$ & $(0.119)$ & $(0.108)$ \\
\hline \multirow{2}{*}{$F_{n j s}^{I}$} & 0.034 & 0.034 & 0.034 \\
& $(0.085)$ & $(0.085)$ & $(0.085)$ \\
\hline$E_{i j s}^{I}$ & -1.639 & -1.562 & -1.568 \\
\hline \multirow{2}{*}{$M L X_{n j s}$} & $0.624^{* * *}$ & $0.623 * * *$ & $0.624^{* * *}$ \\
& $(0.152)$ & $(0.152)$ & $(0.152)$ \\
\hline \multirow{2}{*}{$\left(M L X_{n j s}\right)^{2}$} & $-0.048^{* * *}$ & $-0.048^{* * *}$ & $-0.048^{* * *}$ \\
& $(0.011)$ & $(0.011)$ & $(0.011)$ \\
\hline \multirow{2}{*}{$M_{i}$} & $0.266^{* * *}$ & $0.262^{* * *}$ & $0.263 * * *$ \\
& $(0.089)$ & $(0.089)$ & $(0.089)$ \\
\hline
\end{tabular}


$\langle$ Table 4〉 Extended bioethanol models with different political propensity (continue)

\begin{tabular}{|c|c|c|c|}
\hline Variable & $\mathrm{Fe} 4$ & $\mathrm{Fe} 5$ & Fe6 \\
\hline$\left(M_{i}\right)^{2}$ & $\begin{array}{c}-0.026^{* * *} \\
(0.008)\end{array}$ & $\begin{array}{c}-0.026^{* * * *} \\
(0.008)\end{array}$ & $\begin{array}{c}-0.027 * * * \\
(0.008)\end{array}$ \\
\hline$D_{n}^{\text {cons }}$ & $\begin{array}{l}0.137^{* *} \\
(0.060)\end{array}$ & & \\
\hline$F_{n j s}^{D} * D_{n}^{c o n s}$ & $\begin{array}{l}-0.135 \\
(0.099)\end{array}$ & & \\
\hline$D_{n}^{\text {neutral }}$ & & $\begin{array}{c}-0.059 \\
(0.059) \\
\end{array}$ & \\
\hline$F_{n j s}^{D} * D_{n}^{\text {neutral }}$ & & $\begin{array}{c}0.05 \\
(0.096)\end{array}$ & \\
\hline$D_{n}^{\text {liberal }}$ & & & $\begin{array}{c}-0.212^{* *} \\
(0.103)\end{array}$ \\
\hline$F_{n j s}^{D} * D_{n}^{\text {liberal }}$ & & & $\begin{array}{c}0.235 \\
(0.167)\end{array}$ \\
\hline $\mathrm{LL}(0)$ & -5961 & -5961 & -5961 \\
\hline LL(B) & -5419.11 & -5421.16 & -5419.53 \\
\hline Peudo $\mathrm{R}^{2}$ & 0.091 & 0.091 & 0.091 \\
\hline
\end{tabular}

Notes: $C_{n j}$ : price changes of bioethanol blended gasoline, $F_{n j s}^{D}$ : Dummy for domestic bioethanol with domestic feedstock, $F_{n j s}^{I}$ : Dummy for domestic bioethanol with imported feedstock, $E_{i j s}^{I}$ : imported bioethanol, $M I X_{n j s}$ : Bioethanol blending ratio, $M_{i}$ : income level,

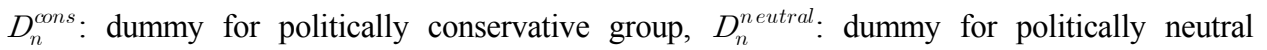

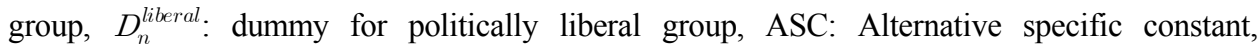
LL(0): Loglikelihood without regressors, LL(B): Loglikelihood with regressors, Pseudo $\mathrm{R}^{2}$ : 1-LL(B)/LL(0)

Standard errors are in parenthesis. $*, * *$, and $* * *$ indicate statistical significance at the $10 \%$, $5 \%$, and $1 \%$ levels, respectively.

\section{Parameter estimates for awareness on environment and bioethanol}

There are two variables for awareness of environment; $e n v_{n}^{1}$ : relative importance of ethanol on reduction of $\mathrm{CO}_{2}$ emission to other benefits and $e n v_{n}^{2}$ : relative importance of environmental conservation compared with economic growth and fairness of income. There is one variable for awareness of bioethanol; $e n v_{n}^{3}$ : 
awareness of bioethanol for transport fuel. As shown in FE7 and FE8 of table 5, as people think bioethanol is more important for reducing $\mathrm{CO}_{2}$ emission and environmental conservation is more important than fairness of income or economic growth, their choice probability of bioethanol decreases, but the interaction term of $e n v_{n}^{2}$ for domestic bioethanol with domestic feedstock has a significant and positive sign. According to the results, people who believe that environment has priority or the most important benefit from bioethanol is $\mathrm{CO}_{2}$ emission evaluate that bioethanol is not appropriate alternative to climate change or environmental conservation.

According to the estimates of FE9 model in table 5, people who already know that bioethanol can be used as an alternative of transport fuels have lower probability of choosing a bioethanol blended gasoline. Again, people who are already exposed to the information on the use of bioethanol as transport fuel suspect that bioethanol can provide various social benefits such as reduction in $\mathrm{CO}_{2}$ emission, relevant rural and industrial development, and increase in energy security.

〈Table 5〉 Extended bioethanol models with different environmental awareness measures

\begin{tabular}{c|c|c|c}
\hline Variable & $F e 7$ & $F e 8$ & fe9 \\
\hline \multirow{2}{*}{$C_{n j}$} & $-0.030^{* * * *}$ & $-0.030^{* * *}$ & $-0.030^{* * *}$ \\
& $(0.002)$ & $(0.002)$ & $(0.002)$ \\
\hline \multirow{2}{*}{$F_{n j s}^{D}$} & $1.446^{* * *}$ & $1.481^{* * *}$ & $1.499^{* * *}$ \\
& $(0.316)$ & $(0.109)$ & $(0.115)$ \\
\hline \multirow{2}{*}{$F_{n j s}^{I}$} & 0.034 & 0.036 & 0.034 \\
& $(0.085)$ & $(0.085)$ & $(0.085)$ \\
\hline \multirow{2}{*}{$E_{n j s}^{I}$} & -1.48 & -1.517 & -1.533 \\
\hline \multirow{2}{*}{$M L X_{n j s}$} & $0.623^{* * *}$ & $0.622^{* * *}$ & $0.624 * * *$ \\
& $(0.152)$ & $(0.152)$ & $(0.152)$ \\
\hline \multirow{2}{*}{$\left(M L X_{n j s}\right)^{2}$} & $-0.048^{* * *}$ & $-0.048^{* * *}$ & $-0.048^{* * *}$ \\
& $(0.011)$ & $(0.011)$ & $(0.011)$ \\
\hline \multirow{2}{*}{$M_{i}$} & $0.268^{* * *}$ & $0.275^{* * *}$ & $0.253^{* * *}$ \\
& $(0.089)$ & $(0.089)$ & $(0.089)$ \\
\hline
\end{tabular}


〈Table 5〉 Extended bioethanol models with different environmental awareness measures (continue)

\begin{tabular}{|c|c|c|c|}
\hline Variable & $\mathrm{Fe} 7$ & $\mathrm{Fe} 8$ & fe9 \\
\hline$\left(M_{i}\right)^{2}$ & $\begin{array}{c}-0.027 * * * \\
(0.008)\end{array}$ & $\begin{array}{c}-0.027 * * * \\
(0.008)\end{array}$ & $\begin{array}{c}-0.025 * * * \\
(0.008)\end{array}$ \\
\hline$e n v_{n}^{1}$ & $\begin{array}{c}-0.081 * * \\
(0.041)\end{array}$ & & \\
\hline$F_{n j s}^{D} * e n v_{n}^{1}$ & $\begin{array}{l}-0.025 \\
(0.067)\end{array}$ & & \\
\hline$e n v_{n}^{2}$ & & $\begin{array}{l}-0.003 \\
(0.074)\end{array}$ & \\
\hline$F_{n j s}^{D} * e n v_{n}^{2}$ & & $\begin{array}{c}0.396 * * * \\
(0.122)\end{array}$ & \\
\hline$e n v_{n}^{3}$ & & & $\begin{array}{c}-0.119^{* *} \\
(0.059)\end{array}$ \\
\hline$F_{n j s}^{D} * e n v_{n}^{3}$ & & & $\begin{array}{c}0.124 \\
(0.096) \\
\end{array}$ \\
\hline LL(0) & -5961 & -5961 & -5961 \\
\hline LL(B) & -5417.7 & -5413.35 & -5419.62 \\
\hline Peudo $\mathrm{R}^{2}$ & 0.091 & 0.092 & 0.091 \\
\hline
\end{tabular}

Notes: $C_{n j}$ : price changes of bioethanol blended gasoline, $F_{n j s}^{D}$ : Dummy for domestic bioethanol with domestic feedstock, $F_{n j s}^{I}$ : Dummy for domestic bioethanol with imported feedstock, $E_{n j s}^{I}$ : imported bioethanol, $M L X_{n j s}$ : Bioethanol blending ratio, $M_{i}$ : income level, $e n v_{n}^{1}$ : relative importance of ethanol on reduction of $\mathrm{CO}_{2}$ emission to other benefits such as development of rural economy, relevant industrial development, and substitution for fossil fules, $e n v_{n}^{2}$ : relative importance of environmental conservation compared with economic growth and fairness of income, $e n v_{n}^{3}$ : awareness of bioethanol for transport fuel, ASC: Alternative specific constant, LL(0): Loglikelihood without regressors, LL(B): Loglikelihood with regressors, Pseudo $\mathrm{R}^{2}$ : 1 -LL(B)/LL(0)

Standard errors are in parenthesis. *, **, and *** indicate statistical significance at the $10 \%$, $5 \%$, and $1 \%$ levels, respectively.

\section{Estimation of mean and standard error of WTP}

Mean value of willingness to pay (WTP) for domestic bioethanol with domestic material was calculated as about $52.34 \mathrm{KRW}$ per liter based on the basic fixed 
effect model in table 2. WTPs for other attributes such as domestic bioethanol with imported feedstock or imported bioethanol were not estimated as they are insignificant. WTP for bioethanol blending ratio was not estimated as well as it is not our interest of concern. The WTP for an attribute A with regard to a monetary attribute $\mathrm{C}$ can be derived from the equation (7) which implies the marginal rate of substitution between the attribute $\mathrm{A}$ and the monetary attribute $\mathrm{C}$ (Kerr and Sharp, 2009).

$$
W T P=-\frac{\partial U / \partial A}{\partial U / \partial C}=-\frac{\beta_{A}}{\beta_{C}}
$$

Variance of WTP was calculated by using the equation (8) the formula developed by Scarpa and Rose (2008).

$$
\operatorname{Var}(W T P)=\left[\operatorname{Var}\left(\beta_{A}\right)+\beta_{A}^{2} / \beta_{C}^{2} \operatorname{Var}\left(\beta_{C}\right)-2 \beta_{A} / \beta_{C} C O V\left(\beta_{A}, \beta_{C}\right)\right] / \beta_{C}{ }^{2}
$$

Covariance between the attribute $\mathrm{A}$ and monetary attribute $\mathrm{C}$ was calculated by variance-covariance matrix for all attributes 6 ). The sample variance of the WTP for domestic bioethanol with domestic matrial was about 32.9 and standard error of the WTP was about 5.74. So, the mean value of the WTP is statistically significant within $1 \%$ level as the $\mathrm{t}$ value is 9.12 which is much larger than 4.5 , the critical value of $\mathrm{t}$ with 8 of degrees of freedom at the $1 \%$ significance level. The lower limit of the mean WTP is $46.5 \mathrm{KRW} /$ liter and the upper limit of the mean WTP is 58.17KRW/liter.

6) Refer to table a5 in the appendice for covariance matrix for bioethanol attributes. 
〈Table 6〉 Estimation of WTP for domestic bioethanol with domestic material

\begin{tabular}{c|c}
\hline \multicolumn{1}{c|}{ Model } & Basic fixed effect model \\
\hline $\begin{array}{c}\text { Mean of WTP estimate on domestic bioethanol with domestic } \\
\text { feedstock }\end{array}$ & 52.3385 \\
\hline $\begin{array}{c}\text { Lower limit of WTP estimate on domestic bioethanol with } \\
\text { domestic feedstock }\end{array}$ & 46.5029 \\
\hline Upper limit of WTP estimate & 58.1741 \\
\hline Variance of WTP estimate & 32.9140 \\
\hline Standard error of WTP estimate & 5.7371 \\
\hline t-value of WTP estimate & 9.1229 \\
\hline
\end{tabular}

\section{Turning points of income and blending ratios}

The basic panel fixed effect estimates show that income levels affect choice probability of bioethanol non-linearly. Figure 1 indicates the inversed $U$ shaped curve between income levels and choice probability for bioethanol. Turning point of income levels was calculated as about income level 5, which lies between 250 and 299million KRW. Therefore at the left hand side of this income level 5, bioethanol choice probability will increase as income increases, while at the right hand side of the turning point, the probability will diminish as income increases.

I used the logit equation for plotting the inversed $U$ shaped curve between income and bioethanol choice probability (equation 9) (Manski and Lerman, 1977). All the values for regressors $(\mathrm{X})$ are mean values except linear and square terms for income levels and all the coefficient estimates are based on the basic fixed effect model in table 2 .

$$
Y_{n s}(j)=\frac{\exp (\bar{x} \hat{b})}{1+\exp (\bar{x} \hat{b})}
$$


〈Figure 1〉 Inversed $U$ shaped relation between income levels and choice probability of bioethanol

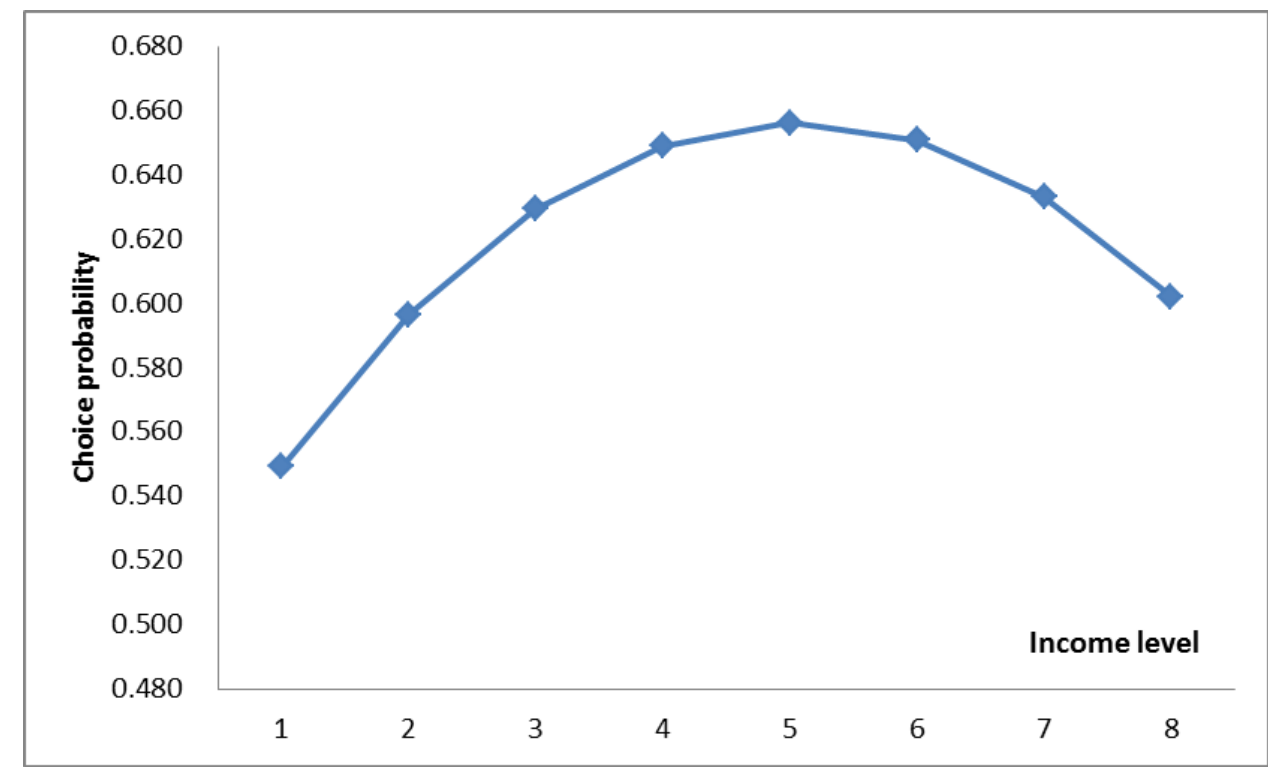

Notes: I used the basic fixed effect model in plotting the relation between income groups and choice probability of bioethanol. Income levels are categorized into 8 brackets. Level 1 implies the lowest income bracket $(\leq 990,000 \mathrm{KRW})$. Each income level increases by $500,000 \mathrm{KRW}$ until level 5, so level 5 is between 2,500,000 and 2,990,000 KRW. Level 6 is between 3,000,000 and 3,990,000, level 7 is between 4,000,000 and 4,990,000, level 8 is equal to or larger than $5,000,000 \mathrm{KRW}$.

Similar to the relation between the income and the bioethanol choice probability, the panel fixed effect models revealed inversed $U$ shaped curve between bioethanol blending ratio and bioethanol choice probability. Figure 2 shows the non-linear relationship between the bioethanol blending ratio and bioethanol choice probability. The same logit equation was applied to plot the curve.

Turning point of bioethanol blending ratio was about $6.5 \%$, so at the left hand side of this point, as the bioethanol blending ratio increases, the likelihood of people's choice of bioethanol will increase, while at the right hand side of the turning point, the probability will decline. 
〈Figure 2〉 Inversed $U$ shaped relation between bioethanol blending ratio (\%) and choice probability of bioethanol

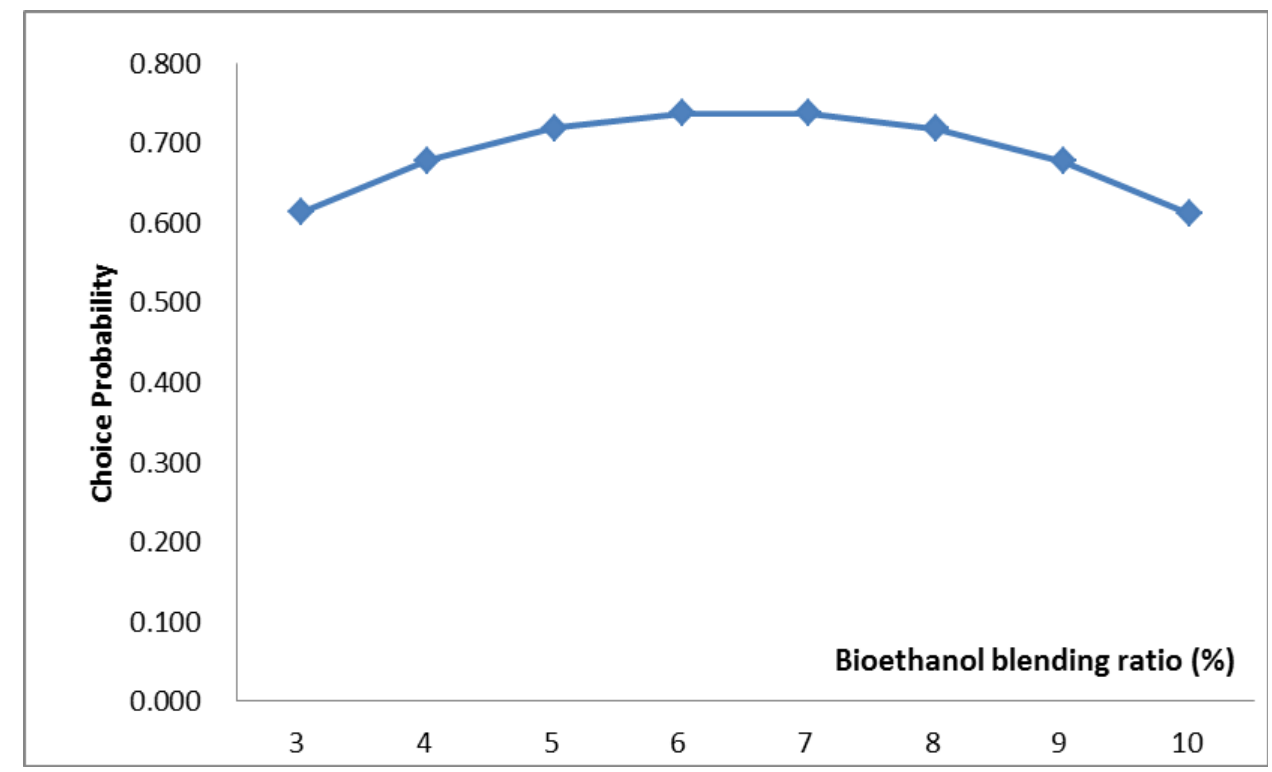

Notes: I used the basic fixed effect model in plotting the relation between income groups and choice probability of bioethanol. Bioethanol blending ratio begins with $3 \%$ blending with petroleum and it increases by $1 \%$ until $10 \%$ blending with petroleum.

\section{Conclusions}

Before Korean government introduces renewable fuel standard (RFS) policy, we need to know value as well as preference structure of potential consumers of renewable fuels. We attemped to reveal WTP for bioethanol as one of the main renewable transport fuels and examine that personal characteristics such as age, sex, education, and income as well as political propensity and environmental awareness can affect preference on bioethanol. Our choice experiment on the supply pathways of bioethanol in the Republic of Korea revealed that Korean gasoline drivers prefer purely domestic bioethanol to imperfect domestic as well as imported bioethanol as an appropriate supply method of bioethanol. The mean and standard error of WTP 
for domestic bioethanol with domestic feedstock within E10 was $52.34 \mathrm{KRW} /$ liter and 5.74 KRW/liter. The lower and upper bound of the mean value of WTP for domestic bioethanol with domestic feedstock were 46.5 and $58.17 \mathrm{KRW} /$ liter.

More interestingly, the outcome found that Korean people have an inverse U shaped (concave) preference on the bioethanol blending ratio to gasoline. This finding implies that the chance of choosing bioethanol will increase at first, but will begin to diminish at the turning point of bioethanol blending ratio. The turning point of bioethanol blending ratio was estimated as 6.5\%. This inverse $U$ shaped curve was observed as well in relation between income level and probability of choosing bioethanol. So, the turning interval of the inverse $U$ shaped curve for the relation between income groups and the choice probability of bioethanol blending fuel was estimated as 2,500,000 and 2,990,000 KRW.

In addition, I found that sex, age, and education as well as their interaction terms with dummy for domestic bioethanol with domestic feedstock do not affect significantly preference of bioethanol blending gasoline. But political propensity and environmental awareness are found to affect significantly the choice of bioethanol blended gasoline. Conservative people preferred to choose bioethanol blended gasoline while progressive people showed weaker preference on bioethanol blended ethanol. With regard to the impacts of environmental awareness on the preference of bioethanol blended gasoline, we found unusual outcome such that people who are not only more concerned with environmental conservation but also regard most important gains from bioethanol as $\mathrm{CO}_{2}$ emission reduction have lower preference on the bioethanol blended gasoline.

According to the findings from this study, Korean government should take into account of what would be the feasible domestic bioethanol price that does not exceed people's WTP for bioethanol that can be produced in Korea. If the bioethanol blended gasoline price is still higher than the conventional gasoline price in spite of a government subsidy, alternative ways to flourish energy security and environmental 
conservation might be considered. Although the price of bioethanol-blended gasoline can be supported by a government subsidy, the socially desirable blending ratio can be restrictive. Hence, the government may have to control the maximum blending ratio within $6.5 \%$ where marginal utility of consuming bioethanol blended gasoline is equal to zero.

There are several limitations in the choice experimental survey for this study. First, it is plausible that the reference price levels differ considerably across regions. Seoul metropolitan areas or other mega cities may have higher reference prices relative to small cities. So, it would be better if reference price levels are set differently for different regions as WTP for bioethanol consumption would be affected by different reference price levels. Second, the survey would produce more reliable results on the WTP if questions on whether respondents pay the fuel cost by themselves or not. If the fuel costs are paid by their companies or other persons, they would not concern carefully over the price increases due to the blending of bioethanol with gasoline. Third, the design of the survey questionnaire is incompatible with the RFS of Korea and assumes orthogonality among the following four interrelated attributes: (i) domestic or offshare procurement of feedstocks in the case of domestic production, (ii) domestic production or import of bioethanol, (iii) the blending ratios, and (iv) the retail price increases. In addition, the results of model estimation and of model selection test are not definite. Hence, the results in this study should not be directly applied to the design of the specifics of the Korean RFS.

\section{[References]}

1. Bergmann, A., Colombo, S., Hanley, N., (2008). Rural versus urban preferences for renewable energy developments. Ecological Economics 65, 616-625. 
2. Bergmann, A., Hanley, N., Wright, R., (2006). Valuing the attributes of renewable energy investments. Energy Policy 34, 1004-1014.

3. Botchers, A.M., Duke, J.M., Parsons, G.R., (2007). Does willingness to pay for green energy differ by source? Energy Policy 35, 3327-3334.

4. Davidson, D.J., Freudenburg, W.R., 1996. Gender and environmental risk concerns: a review and analysis of available research. Environment and Behavior 28, 302-339.

5. de Gorter, Harry and Just, David R., 2007, The Welfare Economics of an Excise-Tax Exemption for Biofuels, MPRA Paper No. 5151.

6. Ferrish, J. and Joshi, S.V., 2004, Evaluating the Impacts of an Increase in Fuelethanol Demand on Agriculture and the Economy, Selected Paper prepared for presentation at the American Agricultural Economics Association Annual Meeting, Denver, Colorado.

7. Greene, W. (2000), Econometric Analysis, $4^{\text {th }}$ edn, Prentice Hall, Upper Saddle River, NJ.

8. Heiman, M.K., Solomon, B.D., (2007), Fueling U.S. transportation: the hydrogen economy and its alternatives. Environment 49 (8), 10-25.

9. Hill, J., Nelson, E., Tilman, D., Polasky, S., Tiffany, D., (2006). Environmental, economic, and energetic costs and benefits of biodiesel and ethanol biofuels. Proceedings of the National Academy of Sciences 103, 11206-11210.

10. Jaffe, A., Savins, R., 1994. Energy-efficiency investments and public policy. The Energy Journal 15 (2), 43-65.

11. Jeanty, P., and F. Hitzhusen (2007), Using stated preferences to estimate the environmental benefits of using biodiesel fuel in diesel engines, Biofuels, Food, and Feed Tradeoffs Conference St. Louise, MO.

12. KALIA (Korea Alcohol and Liquor Industry Association), 2012, Financial accounting data for individual alcoholic company, Accessed at http://www.kalia.or.kr.

13. Kerr, G., Sharp, B., 2009, Efficiency benefits of choice model experimental design updating: a case study, Presented paper in the 53th annual Australian Agriculture and Resource Economics Society Conference, Cairns, Queensland.

14. Li, H., Jenkins-Smith, H., Silva, C.L., Berrens, R.P., Herron, K.G., 2009. Public support for reducing US reliance on fossil fuels: investigating household willingness- 
to-pay for energy research and development. Ecological Economics 68, 731-742.

15. Lim, Y., 2012. Literature review, main issues, and future direction in introducing RFS policy in South Korea, A presentation paper for Korea Petroleum Quality \& Distribution Authority.

16. Longo, A., Markandya, A., Petrucci, M., 2008. The internalization of externalities in the production of electricity: willingness to pay for the attributes of a policy for renewable energy. Ecological Economics 67, 140-152.

17. Manski, C. and S. Lerman (1977), "The estimation of choice probabilities from choice based samples', Econometrica 45, 1977-1988.

18. Marschak, J. (1960), 'Binary choice constraints on random utility indications', in K. Arrow, ed., Stanford Symposium on Mathematical Methods in the Social Sciences, Stanford University Press, Stanford, CA, pp. 312-329.

19. McFadden, D,. "Conditional Logit Analysis of Qualitative Choice Behavior," Zarembka, ed., Frontiers in Econometrics, New York : Academic Press, 1974.

20. Petrolia, Daniel R., Sanjoy Bhattacharjee, Darren Hudson, Cary W. Herndon (2010), Do Americans want ethanol? A comparative contingent-valuation study of willingness to pay for E-10 and E-85, Energy Economics 32, 121-128.

21. Petronet, 2012, Domestic retail gasoline price data, Accessed at http://www. petronet.co.kr.

22. Rabe, B., 2007. Beyond Kyoto: designing policies to reduce greenhouse gases in competing federal systems. Governance: An International Journal of Policy, Administration and Institutions 20, 423-444.

23. Roe, B., Teisl, M.F., Levy, A., Russell, M., 2001. US consumers' willingness to pay for green electricity. Energy Policy 29, 917-925.

24. Runge, C.F., Senauer, B., 2007. How biofuels could starve the poor. Foreign Affairs 86 (3), 41-53.

25. Scarpa, R. and Willis, K., 2010. "Willingness to pay for renewable energy : Primary and discretionary choice of British households' for micro-generation technologies, Energy Economics vo. 32, pp. 129-136.

26. Scarpa, R. and Rose, J.M., 2008, "Design efficiency for non-market valuation with choice modeling : how to measure it, what to report and why", Australian Journal 
of Agricultural and Resource Economics 52, 253-282.

27. Solomon, Barry D. and Nicholas H. Johnson, (2009), Valuing climate protection through willingness to pay for biomass ethanol, Ecological Economics 68, 2137-2144.

28. Train, K.E., 2009. Discrete Choice Methods with Simulation. Cambridge University Press, Cambridge.

29. Vedenov, D. and Wetzstein, M., 2008, Toward an optimal U.S. ethanol fuel subsidy, Energy Economics 30, 2073-2090.

30. Wiser, R.H., 2007. Using contingent valuation to explore willingness to pay for renewable energy: a comparison of collective and voluntary payment vehicles. Ecological Economics 62, 19-32.

40. World Bank, 2008. Biofuels: The Promise and the Risk, Policy Brief, World Development Report 2008. Agriculture and Development, Washington,D.C.http:// econ.worldbank.org/WBSITE/EXTERNAL/EXTDEC/EXTRESEARCH/EXTWDRS/E XTWDR2008/0,,contentMDK:21501336 pagePK:64167689 piPK:64167673 theSiteP K:2795143,00.html.

41. Zarnikau, J., 2003. Consumer demand for 'green power' and energy efficiency. Energy Policy 31, 1661-1672. 


\section{[Appendice]}

〈Table a1〉 Comparison of effects among different bioethanol production pathways

\begin{tabular}{c|c|c|c}
\hline $\begin{array}{c}\text { Types of bioethanol } \\
\text { supply }\end{array}$ & $\begin{array}{c}\text { Domestic ethanol } \\
\text { with domestic } \\
\text { feedstock }\end{array}$ & $\begin{array}{c}\text { Domestic ethanol } \\
\text { with imported } \\
\text { feedstock }\end{array}$ & Import of ethanol \\
\hline $\begin{array}{c}\text { Development of } \\
\text { agricultural sector }\end{array}$ & $\bigcirc$ & $\mathrm{X}$ & $\mathrm{X}$ \\
\hline $\begin{array}{c}\text { Development of ethanol } \\
\text { industry }\end{array}$ & $\bigcirc$ & $\checkmark$ & $\mathrm{X}$ \\
\hline $\begin{array}{c}\text { Domestic energy } \\
\text { production effect }\end{array}$ & $\bigcirc$ & $\triangle$ & $\triangle$ \\
\hline $\begin{array}{c}\text { Mitigation of green } \\
\text { house gases }\end{array}$ & $\bigcirc$ & $\triangle$ & $\mathrm{X}$ \\
\hline $\begin{array}{c}\text { Necessity of government } \\
\text { subsidy }\end{array}$ & $\bigcirc$ & $\triangle$ & \\
\hline
\end{tabular}

( $\bigcirc$ : very positive effect, $\triangle$ : mild effect, $X:$ no effect/neutral)

〈Table a2〉 Mitigation of green house gases according to different blending ratios of bioethanol

\begin{tabular}{c|c|c}
\hline Blending ratio of bioethanol & $\begin{array}{c}\text { Substitution of gasoline } \\
\text { (Unit: 1,000 liter) }\end{array}$ & $\begin{array}{c}\text { Mitigation of green house } \\
\text { gases (Unit: ton) }\end{array}$ \\
\hline $3 \%$ of bioethanol blending & 300,000 & $100,000 \sim 250,000$ \\
\hline $5 \%$ of bioethanol blending & 500,000 & $170,000 \sim 410,000$ \\
\hline $10 \%$ of bioethanol blending & $1,000,000$ & $240,000 \sim 580,000$ \\
\hline
\end{tabular}

〈Table a3〉 Attributes and levels of alternative bioethanol for the choice experiment

\begin{tabular}{c|l}
\hline Attribute & \multicolumn{1}{c}{ Level } \\
\hline $\begin{array}{c}\text { Price changes } \\
\text { of gasoline }\end{array}$ & 1) Increase of $20 \mathrm{KRW}$ per liter in gasoline price \\
& $\begin{array}{c}\text { 2) Increase of } 80 \mathrm{KRW} \text { per liter in gasoline price } \\
\text { 3) Increase of } 120 \mathrm{KRW} \text { per liter in gasoline price }\end{array}$ \\
\hline $\begin{array}{c}\text { Method of } \\
\text { providing }\end{array}$ & $\begin{array}{l}\text { 1) Use of domestic feedstock for domestic bioethanol: Domestic barley is } \\
\text { used for producing domestic bioethanol }\end{array}$ \\
bioethanol & $\begin{array}{l}\text { Use of imported feedstock for domestic bioethanol: Tapioca is imported } \\
\text { for producing domestic bioethanol }\end{array}$ \\
& 3) Import of bioethanol : Bioethanol is imported \\
\hline
\end{tabular}


〈Table a3〉 Attributes and levels of alternative bioethanol for the choice experiment (Continued)

\begin{tabular}{c|l}
\hline Attribute & \multicolumn{1}{c}{ Level } \\
\hline & 1) $3 \%$ of bioethanol blending \\
Blending ratios & 2) $5 \%$ of bioethanol blending \\
of bioethanol & 3) $10 \%$ of bioethanol blending \\
to gasoline & $\begin{array}{c}\text { There is no significant damage to the performance of a car even if } 10 \% \\
\text { of bioethanol is blended with gasoline }\end{array}$ \\
\hline
\end{tabular}

〈Table a4〉 Basic statistics for respondents in the choice experiment survey

\begin{tabular}{|c|c|c|c|}
\hline & & Observations (person) & Percentage \\
\hline \multicolumn{2}{|r|}{ Total } & 500 & 100.0 \\
\hline \multirow{2}{*}{ Sex } & Male & 381 & 76.2 \\
\hline & Female & 119 & 23.8 \\
\hline \multirow{5}{*}{ Age } & $19-29$ & 31 & 6.2 \\
\hline & $30 \mathrm{~s}$ & 89 & 17.8 \\
\hline & $40 \mathrm{~s}$ & 149 & 29.8 \\
\hline & $50 \mathrm{~s}$ & 210 & 42.0 \\
\hline & $60 \mathrm{~s}$ and over & 21 & 4.2 \\
\hline \multirow{6}{*}{ Region } & Seoul & 89 & 17.8 \\
\hline & Inchon/Gyeonggido & 145 & 29.0 \\
\hline & Chungchungdo & 53 & 10.6 \\
\hline & Gyeongsangdo & 145 & 29.0 \\
\hline & Joenlado & 47 & 9.4 \\
\hline & Gangwon/Jeju & 21 & 4.2 \\
\hline \multirow{5}{*}{ Education } & Elementary & 1 & 0.2 \\
\hline & Middle school & 24 & 4.8 \\
\hline & High school & 231 & 46.2 \\
\hline & University & 234 & 46.8 \\
\hline & Graduate school & 10 & 2.0 \\
\hline \multirow{5}{*}{ Income } & Less than 3,000 thousand KRW & 128 & 25.6 \\
\hline & 3,000-4,000 thousand KRW & 156 & 31.2 \\
\hline & 4,000-5,000 thousand KRW & 139 & 27.8 \\
\hline & 5,000 thousand KRW & 74 & 14.8 \\
\hline & Unknown & 3 & 0.6 \\
\hline
\end{tabular}


〈Table a5〉 Covariance matrix for bioethanol attributes

\begin{tabular}{c|c|c|c|c|c|c|c}
\hline$e(V)$ & $C_{n j}$ & $F_{n j s}^{D}$ & $F_{n j s}^{I}$ & $M I X_{n j s}$ & $\left(M L X_{n j s}\right)^{2}$ & $M_{i}$ & $\left(M_{i}\right)^{2}$ \\
\hline$C_{n j}$ & 0.000003 & & & & & & \\
\hline$F_{n j s}^{D}$ & -0.000105 & 0.011394 & & & & & \\
\hline$F_{n j s}^{I}$ & -0.000020 & 0.004539 & 0.007196 & & & & \\
\hline$M L X_{n j s}$ & 0.000180 & -0.007008 & -0.003776 & 0.023194 & & & \\
\hline$\left(M L X_{n j s}\right)^{2}$ & -0.000013 & 0.000523 & 0.000284 & -0.001694 & 0.000124 & & \\
\hline$M_{i}$ & -0.000002 & 0.000094 & 0.000001 & 0.000033 & -0.000003 & 0.007910 & \\
\hline$\left(M_{i}\right)^{2}$ & 0.000000 & -0.000009 & 0.000000 & -0.000003 & 0.000000 & -0.000698 & 0.000064 \\
\hline
\end{tabular}

Notes: $C_{n j}$ : price changes of bioethanol blended gasoline, $F_{n j s}^{D}$ : Dummy for domestic bioethanol with domestic feedstock, $F_{n j s}^{I}$ : Dummy for domestic bioethanol with imported feedstock, $E_{n j s}^{I}$ : imported bioethanol, $M I X_{n j s}$ : Bioethanol blending ratio, $M_{i}$ : income level

〈Figure a1〉 A sample choice set

\begin{tabular}{|c|c|c|c|}
\hline Q 10-1) Type 1 & Bioethanol A & Bioethanol B & No choice \\
\hline Gasoline price per liter & $\begin{array}{c}\text { Increase of } 80 \\
\text { KRW/liter }\end{array}$ & $\begin{array}{c}\text { Increase of } 20 \\
\text { KRW/liter }\end{array}$ & \\
\hline $\begin{array}{l}\text { Method of providing } \\
\text { bioethanol }\end{array}$ & $\begin{array}{c}\text { Use of imported } \\
\text { feedstock for domestic } \\
\text { bioethanol }\end{array}$ & Import of bioethanol & \\
\hline $\begin{array}{l}\text { Blending ratios of bioethanol } \\
\text { to gasoline }\end{array}$ & $3 \%$ & $3 \%$ & \\
\hline $\begin{array}{l}\text { The most preferred } \\
\text { alternative }\end{array}$ & (1) & (2) & (3) \\
\hline
\end{tabular}


〈Figure a2〉 The original survey questionnaire

\section{바이오에탄올에 관한 인식 조사 $(\mathrm{A})$}

문1) $O O$ 넘께서는 주유소를 선택 하실 때 다음 항목들을 얼마나 중요하게 고려하십니까?

\begin{tabular}{|c|c|c|c|c|c|}
\hline 주윯소 섬택 기준 & $\begin{array}{c}\text { 매우 } \\
\text { 긍요하다 }\end{array}$ & $\begin{array}{c}\text { 약가 } \\
\text { 긍요하다 }\end{array}$ & $\begin{array}{l}\text { 보등 } \\
\text { 이다 }\end{array}$ & 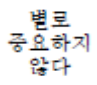 & $\begin{array}{c}\text { 정형 } \\
\text { 요한다자 }\end{array}$ \\
\hline 1) 휘발유 팠애 가격 (q1a1) & (1) & (2) & (3) & (4) & (5) \\
\hline 2) 주윳소까지의 거리 (q1a2) & (1) & (2) & (3) & (4) & (5) \\
\hline 3) 주윴소 브랬드(SK, 혔대, S오일, GS칼텍스 등) (q1a3) & (1) & (2) & (3) & (4) & (5) \\
\hline 4) 셀프 주뀽소 여부 (q1a4) & (1) & (2) & (3) & (4) & (5) \\
\hline 5) 사은퐇, 세차 할있결 등 부대 서비스 (q1a5) & (1) & (2) & (3) & (4) & (5) \\
\hline
\end{tabular}

문2) 00 님께서 운전하시고 있는 자동차는 다음의 유형 중 어디에 속합니까? (2)

(1) 경형 승용차 (1,0000 미만) (예: 마비즈/스파크, 모넝, 아토즈, 비스토, 레이 등)

(2) 소형승용차 (1,000cc-1,5000c 미만) (예: 아베오, 엑센트, 프라이트, 라노스 등)

(3) 준긍형승용차 $(1,50000-1,8000 \mathrm{c}$ 미만) (예: 타서티, 아반떠, 세타토, 프르테, 뉴SMB 등)

(4) 긍형승용차 (1,800 cc-2,0000c 미만) (예: 소나타, K5, SM5, 달리부, 코체, 토스카 등)

(5) 대형승왕차 (2,000 cc 이상) (예: 그탠저, $\mathrm{SM} 7, \mathrm{~K}$, 오펴러스, 체어맨, 에쿠스, 제녀시스 등)

(6) 스포츠승용차 (예: 투스카너, 엘란, 티뷰톤 등)

(7) RV형 MPV (예: 레조, 카린스, 트라제 등)

(8) RV형 SUV (예: 스프티지, 투손, 원스폼 등)

문3) 00 넘의 하루 평귤 운행 거리는 대략 얼마 정도나 되십니까? $\mathrm{km}$ 단위로 말씀해 주십시오. (q3)
(1) $10 \mathrm{~km}$ 이하
(2) $11 \sim 20 \mathrm{~km}$ 이하
(3) $21 \mathrm{~km} \sim 30 \mathrm{~km}$ 이하
(4) $31 \mathrm{~km}$ 이상

문4) 00 님께서 평소 자동차를 이용하는 가장 주된 목적은 무엇입니까? (q4)
(1) 출퇴근용
(2) 업무용
(3) 자녀의 학교 등하고용
(4) 레저 8
(5) 쇼평용
(6) 기타 (구체젹으로 :

문5) 00 넘 자동차의 평귤 엷비는 1 리터당 대략 얼마나 되십니까? 자동차에 표시되어 있는 공인연비와 관계없이 실제로 0 임이 운전하시면서 느끼시는 체감 연비를 기준으로 말씀해 주십시오. (q5)
(1) $10 \mathrm{~km} /$ 리터 이하
(2) $11 \sim 20 \mathrm{~km} /$ 리터 이하
(3) $21 \mathrm{~km} /$ 리텨 이상 
〈Fig. a2〉 The original survey questionnaire (Continued)

문6) 0 O님께서는 조유비로 한달 평균 얼마를 지출하고 계십니까? 만뭔 단위로 말씀해 주십시오. (96)
(1) 10 만원 이하
(2) $11 \sim 20$ 란원 이하
(3) 21 30만원 이하
(4) 31 만원 이상

문7) 바이오에탄올이란, 사탕수수, 옥수수, 보리, 타피오카 등율 발호하여 만 픔 자동차용 영료로 휘발유를 대체 할 수 있습니다. 이디 유럽과 미국 등에서 연료로 사용되고 있습니다. 00 님꼐서는 바이오에탄올에 대해 들어본 경험이 있으십니까? (q7)
(1) 들어본 젹 있다
(2) 들어본 젹 없다

문8) 바이오에탄올은 다음과 같은 다양한 긍정적 효과가 있는 것으로 알려져 있습니다. $\bigcirc$ ㄴ님께서는 다음의 각 효과들이 얼마나 중요하다고 생각하십니까?

\begin{tabular}{|c|c|c|c|c|c|}
\hline 바이오에탄올의 궁정적 효과 & $\begin{array}{l}\text { 매우 } \\
\text { 증요하다 }\end{array}$ & 긍요교하다 & $\begin{array}{l}\text { 보등 } \\
\text { 이다 }\end{array}$ & $\begin{array}{l}\text { 별로 } \\
\text { 긍요하지 } \\
\text { 않다 }\end{array}$ & $\begin{array}{l}\text { 건혀 } \\
\text { 긍요하지 } \\
\text { 않다 }\end{array}$ \\
\hline $\begin{array}{l}\text { 1. 온실가스 배출랑을 줄여 지구온난화 문제 해결에 } \\
\text { 도움이 됨 (q8a1) }\end{array}$ & (1) & (2) & (3) & (4) & (5) \\
\hline $\begin{array}{l}\text { 2. 보리나 고구마 등 국산뭔료를 이용함으로써 } \\
\text { 우리나라 농업 보전과 농가소득 향상에 기여함 } \\
\text { (c8a2) }\end{array}$ & (1) & (2) & (3) & (4) & (5) \\
\hline 3. 국내 에탄올 산업 활성화에 기여함 (c8a3) & (1) & (2) & (3) & (4) & (5) \\
\hline $\begin{array}{l}\text { 4. 국산에 너지를 생산함으로써 석유와 같은 } \\
\text { 수입 에너지를 대체함 (c8a4) }\end{array}$ & (1) & (2) & (3) & (4) & (5) \\
\hline
\end{tabular}

문9) 바이오에탄올은 휘발유보다 생산비가 더 비싼 것으로 알져져 있습니다. 절부는 바이오에탄올의 다양항 꽇익적 기능을 고려하여 직간젋적인 지뭔절책을 고려하고 있습니다. $\mathrm{O}$ O넘께서는 다음의 각 정첵들이 얼마나 중요하다고 생각하십니까?

\begin{tabular}{|c|c|c|c|c|c|}
\hline 바이오에탈올 지원 정책의 유형 & $\begin{array}{c}\text { 매우 } \\
\text { 증요하다 }\end{array}$ & $\begin{array}{c}\text { 약간 } \\
\text { 긍요하다 }\end{array}$ & $\begin{array}{l}\text { 보등 } \\
\text { 이다 }\end{array}$ & $\begin{array}{c}\text { 별로 } \\
\text { 중요하지 } \\
\text { 않다 } \\
\end{array}$ & $\begin{array}{l}\text { 전혀 } \\
\text { 궁요하지 } \\
\text { 않다 } \\
\end{array}$ \\
\hline 1. 유류세 면세 (tax) & (1) & (2) & (3) & (4) & (5) \\
\hline 2. 주차료 및 고속도로 통행료 할인 (park) & (1) & (2) & (3) & (4) & (5) \\
\hline 3. 친환경 운전자임을 표시하는 스티커 부착 (tag) & (1) & (2) & (3) & (4) & (5) \\
\hline 4. 에탄올 뭔료를 생산하는 농가에 보조금 지뭔 (subsidy) & (1) & (2) & (3) & (4) & (5) \\
\hline
\end{tabular}


〈Fig. a2〉 The original survey questionnaire (Continued)

\section{<보기카드> 바이오에탄을 개요}

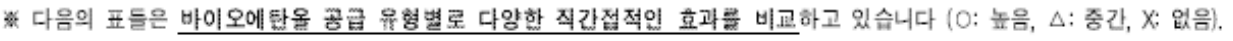
바이오에탄올 공급 유형별로 다양한 효과들을 먼저 숙지하시고 질문에 답해 주시기 바랍니다.

\begin{tabular}{|c|c|c|c|}
\hline 에탐울 공⿳ㅡㅂ 윱형 & $\begin{array}{c}\text { 국산 ㅁㅝㅝ료률 이용한 국산 } \\
\text { 에탄올 제조 }\end{array}$ & $\begin{array}{c}\text { 해외농장에서 뭥료률 } \\
\text { 수읿하여 국산 에탄올 제조 }\end{array}$ & 에탄올 해외 직수잃 \\
\hline 국내농업 활성화 효과 & $\mathrm{O}$ & $x$ & $x$ \\
\hline 국내 에탄올 산업 활성화 효과 & $\mathrm{O}$ & $\mathrm{O}$ & $x$ \\
\hline 국산에 너지 생산 효과 & $\mathrm{O}$ & $\Delta$ & $x$ \\
\hline 온실가스 저감효과 & 0 & $\Delta$ & $\Delta$ \\
\hline 정부 보조금 투입 필요성 & 0 & $\Delta$ & $x$ \\
\hline
\end{tabular}

\begin{tabular}{|c|c|c|}
\hline 윻ㅎㅇㅇ & 회발윯대체랑(당위: 1,000 리터) & 온실가스 저갑랑 \\
\hline 바이오에 탄올을 훼발유에 $3 \%$ 홇합 & 300,000 & 10 만론 - 25만톤 \\
\hline 바이오에탄올을 훼발유에 $5 \%$ 혼합 & 500,000 & 17만론 - 41만론 \\
\hline 바이오에 탄올을 휘발유에 $10 \%$ 홇합 & $1,000,000$ & 24 만톤 - 58만톤 \\
\hline
\end{tabular}

* 다음은 바이오에탄올이 도입되어 휘발유와 혼합되어 판매될 경우 소비자가 고려해야 할 주오 속성뜰을 설명 하고 있습니다. 아래 설명을 찹조하여 다음의 바이오에탄올 유형별 선텍 질문에 답해 주시기 바랍니다.

\begin{tabular}{|c|c|}
\hline 속성 & 설명 \\
\hline $\begin{array}{c}\text { 바이오에탄올 } \\
\text { 가격 변화 }\end{array}$ & $\begin{array}{l}\text { 1) 국내 휘발유 판매 가격 대비 리터당 20ㅇㅝㅝ 상승 } \\
\text { 2) 국내 휘발유 판매 가격 대비 리터당 } 80 \text { 원 상승 } \\
\text { 3) 국내 휘발유 판매 가격 대비 리터당 } 120 \text { 원 상승 }\end{array}$ \\
\hline $\begin{array}{l}\text { 에탄올 뭔류 } \\
\text { 조달 방벏 }\end{array}$ & $\begin{array}{l}\text { 1) 국산ㅁㅝㅝ료사용 : 국산 보리, 고구아 등을 국내에서 생산하여 국내에서 에탄올 생산 } \\
\text { 2) 해외농장조달 : 해외 농장에서 재배한 타피오카, 카사바 등의 뮌료를 수입하여 국내에서에탄올 생산 } \\
\text { 3) 에탄올직수읿 : 해외에서 에탄올을 직수입 함 }\end{array}$ \\
\hline $\begin{array}{c}\text { 바이오에 탄올 } \\
\text { 혼 합비율 }\end{array}$ & $\begin{array}{l}\text { 1) 바이오에탄올을 휘발유에 } 3 \% \text { 혼합 } \\
\text { 2) 바이오에탄올을 휘발유에 } 5 \% \text { 혼합 } \\
\text { 3) 바이오에탄올을 휘발유에 } 10 \% \text { 홇합 }\end{array}$ \\
\hline
\end{tabular}


〈Fig. a2〉 The original survey questionnaire (Continued)

\section{바이오에탄올 보급 방식에 관한 선호도 조사 (B)}

문10) 0 O님페서는 바이오에탄올이 휘발유에 일정 비율 (3 10\%)로 혼합되는 경우, 다을의 선택 유형별로 어뗜 바이오에탄올율 선택하시겠슸니깨? 섰택 유형별로 잘 읽어보시고 각각의 A형과 B형 충 하나씩만 섧택해 주시연 됳니다. 바이오에탄올 도입 자체에 반대하신다연 '선텍 하지 않음'을 선택 하셔도 됩니다.

\begin{tabular}{|c|c|c|c|}
\hline 문 \{0-1) 제 | 섰택형 (q10a1\} & 바이오에탄올 A & 바이오에탄올 B & 섰택 하지 많음 \\
\hline 리버당 가격 & 80 원 증가 & 20원 증가 & \\
\hline 원료조달방식 & 해외농장에서 원료수입 & 에탄을 직수입 & \\
\hline 바이오에탄올 혼합비율 & $3 \%$ & $3 \%$ & \\
\hline 선호하는 율형율 선택해 주싧시오 & (1) & (2) & (3) \\
\hline
\end{tabular}

\begin{tabular}{|c|c|c|c|}
\hline 뭇 10-2) 제 2 섰택형 (q10a2) & 바이오에탄올 A & 바이오에 탄올 B & 섧택 하지 많음 \\
\hline 리터당 가격 & 120 원 증가 & 120 원 증가 & \\
\hline 원 로 조달뱡식 & 해외농장에서 원료수입 & 에탄올 직수입 & \\
\hline 바이오에탄올 혼합비율 & $10 \%$ & $10 \%$ & \\
\hline 선호하는 유형율 섰택해 주싧시오 & (1) & (2) & (3) \\
\hline
\end{tabular}

\begin{tabular}{|c|c|c|c|}
\hline 문 10-3) 제 3 선택형 (q10a3) & 바이오에탄올 A & 바이오에탄올 B & 선택하지 많음 \\
\hline 리터당 가격 & 20 원 증가 & 20원 증가 & \\
\hline 원료.조달방식 & 국산원료사용 & 국산원료사용 & \\
\hline 바이오에탄올 혼합비율 & $10 \%$ & $3 \%$ & \\
\hline 선호하는 유형율 선택해 주싫시오 & (1) & (2) & (3) \\
\hline
\end{tabular}

\begin{tabular}{|c|c|c|c|}
\hline 뭇 10-4) 제 4 선택형 (q10a4) & 바이오에탐올 A & 바이오에탄올 B & 섧택 하지 많음 \\
\hline 리터당 가격 & 20 원 증가 & 80 원 증가 & \\
\hline ㅁㅝㅝ료조달방식 & 에탄올 직수입 & 에탄올 직수입 & \\
\hline 바이오에탄올 혼합비율 & $5 \%$ & $3 \%$ & \\
\hline 선호하는 유형율 섧택해 주실시오 & (1) & (2) & (3) \\
\hline
\end{tabular}

\begin{tabular}{|c|c|c|c|}
\hline 뭇 10-5) 제 5 선택형 (q10a5) & 바이오에탄올 A & 바이오에탄올 B & 선택 하지 많음 \\
\hline 리터당 가격 & 20 원 증가 & 80원 증가 & \\
\hline 뭔료.조달방식 & 해외농장에서 원료수입 & 국산원료사용 & \\
\hline 바이오에탄올 혼합비율 & $5 \%$ & $10 \%$ & \\
\hline 선호하는 유형율 선택해 주싫시오 & (1) & (2) & (3) \\
\hline
\end{tabular}


〈Fig. a2〉 The original survey questionnaire (Continued)

\begin{tabular}{|c|c|c|c|}
\hline 뭇 $10-6\}$ 제 6 섰택형 $(\mathrm{q} 10 \mathrm{a} 6)$ & 바이오에 탄올 A & 바이오에 탄올 B & 섰택하지 많음 \\
\hline 리터당 가격 & 20 원 증가 & 120 원 증가 & \\
\hline 뭔료.조달방식 & 해외농장에서 원료수입 & 국산원료사용 & \\
\hline 바이오에탄올 홓합비율 & $10 \%$ & $3 \%$ & \\
\hline 섰호하늘 유형율 선택해 주싧시오 & (1) & (2) & (3) \\
\hline
\end{tabular}

\begin{tabular}{|c|c|c|c|}
\hline 문 10-7) 제 7 선택형 (q10a7) & 바이오에 탄올 A & 바이오에탄올 B & 섰택하지 많음 \\
\hline 리터당 가격 & 80 원 증가 & 80 원 증가 & \\
\hline 뭔료조달방식 & 국산원료사용 & 에단을 직수입 & \\
\hline 바이오에탄올 혼합비율 & $5 \%$ & $10 \%$ & \\
\hline 섧호하는 융형율 선택해 주싧시오 & (1) & (2) & (3) \\
\hline
\end{tabular}

\begin{tabular}{|c|c|c|c|}
\hline 문10-8) 제 8 섰택형 (q10a8) & 바이오에 탄올 A & 바이오에 탄올 B & 선택하지 많음 \\
\hline 리터당 가격 & 120 원 증가 & 120 원 증가 & \\
\hline 원류.조달방식 & 에탄올 직수입 & 국산원료사용 & \\
\hline 바이오에 탄올 혼 합비율 & $5 \%$ & $5 \%$ & \\
\hline 선호하는 유형을 섭택해 주심시오 & (1) & (2) & (3) \\
\hline
\end{tabular}

\begin{tabular}{|c|c|c|c|}
\hline 물 10-9) 제 9 섰택형 (a10a9) & 바이오에 탄올 A & 바이오에 탄올 B & 섰택 하지 많음 \\
\hline 리터당 가격 & 120 원 증가 & 80 원 증가 & \\
\hline 원류.조달방식 & 해외농장에서 원료수입 & 해외농장에서 원료수입 & \\
\hline 바이오에탄올 혼 합비율 & $3 \%$ & $5 \%$ & \\
\hline 선호하는 유형율 섧택해 주싧시오 & (1) & (2) & (3) \\
\hline
\end{tabular}

\section{자료 분류를 위한 질문}

* 마지막으로 통계처리를 위한 질문입니다.

DQ1) 00 넘께서는 학교를 어디까지 마치셨습니까? (충퇴는 졸얿에 포핣되지 많음) (edㄴ)
(1) 초등학교 졸업 이하
(2) 증학고 졸업
(3) 고등학교 졸업
(4) 건문대/대학교 졸업
(5) 석사 졸업
(6) 박사 졸업 
〈Fig. a2〉 The original survey questionnaire (Continued)

DQ2) 0 O넘 가정의 한달 평균소득은 얼마정도 입니까? 보너스와 이자 수입 등을 포함한 가족 모두의 소득을 월평균으로 말씀해 주십시오. (income)
(1) 99 만원 이하
(2) $100 \sim 149$ 만원
(3) $150 \sim 199$ 만원
(4) 200 249란원
(5) $250 \sim 299$ 만원
(6) $300 \sim 399$ 만원
(7) $400 \sim 499$ 만읜
(8) 500 만원 이상

DQ3) $\mathrm{O}$ O넘의 종교는 무엇입니까? (dq3)
(1) 종교 없음
(2) 불교
(3) 기독교
(4) 천주교 (카톨려)
(5) 기타

DQ4) 0 O님은 종교 행사에 얼마나 자주 참여하십니까? (da4)
(1) 주 1회, 이상
(2) 한 말에 1 회 이상
(3) 1 년에 1희 이상
(4) 감여한 격 없음

DQ5) 0 O넘은 소득 계층간 격차를 줄이기 위해 세금을 지불할 용의가 있습니까? (da5)
(1) 있다
(2) 없다

DQ6) 0 O넘은 경쟁에 의한 효율 개선이 우리 사회에서 얼마나 필요하다고 생각합니까? (da6)
(1) 매우 클요하다
(2) 약간 콜요하다
(3) 별로 플요하지 않다
(4) 건혀 플요하지 앙다

$\mathrm{DQ7)} \mathrm{O}$ O님은 우리나라가 당면한 경제성장과 환경보전, 소득계층간 격차 완화 문제 가운데 어떤 문제가 가장 중요하다고 생각하십니까? 중요하게 생각하시는 순서대로 순위를 매겨 주시기 바랍니다.

\section{1순위 (dq7a1) 2순위 $\quad$ (dq7a2) 3 3슨위 $(\mathrm{dq} 7 \mathrm{a} 3)$}
(1) 경게성장
(2) 환경보전
(3) 소득계층간 격차 완하

$\mathrm{DQB}) 0 \mathrm{O}$ 넘의 정치적 성향은 보수성향에 가깜습니까? 아니면 진보성향에 더 가깝습니까? (da8)
(1) 보수
(2) 증도 보수
(3) 중도
(4) 증도 진보
(5) 진보 